\title{
William Halse Rivers Rivers (1864-1922) and the Sensory Nervous System
}

\author{
J.M.S. Pearce \\ Emeritus Consultant Neurologist, Department of Neurology, Hull Royal Infirmary, Hull, UK
}

\section{Key Words}

William Rivers · Henry Head • Peripheral nerve injury •

Epicritic and protopathic sensation · Shell shock

\begin{abstract}
The polymath William Rivers played an important role in his work with Henry Head in demonstrating the varied, evolving patterns of sensory loss, and epicritic and protopathic sensation, after the section of the superficial ramus of Head's left radial nerve. After a mixed and frustrated army career Rivers devoted his attentions to shell shock and other psychological disturbances which were well received in his time. Siegfried Sassoon and Wilfred Owen were among the distinguished patients whose writings revealed Rivers as the revered object of their gratitude.
\end{abstract}

Copyright $\odot 2008$ S. Karger AG, Base

At the Nobel Prize in Physiology or Medicine in 1944, in his presentation speech, Ragnar Granit, Head of Neurophysiology of the Nobel Institute, made the following statement:

Three great electrophysiological discoveries can be regarded as milestones in the development of our knowledge of nerve physiology. In the middle of the last century, long before Alfred Nobel had bequeathed this great fund to the world, Du Bois-Reymond showed that the nerve impulse was an electrical wave of negativity transmitted along the nerve. Helmholtz made the first measurements of its average speed of propagation in a nerve stem. The

\section{KARGER}

Fax +41613061234

E-Mail karger@karger.ch

www.karger.com (c) 2008 S. Karger AG, Basel

$0014-3022 / 08 / 0604-0208 \$ 24.50 / 0$

Accessible online at:

www.karger.com/ene second great discovery, rewarded with a share in the Nobel Prize for 1932, was Adrian's observation that sense organs and nerve cells discharge whole series of such impulses. In each individual fibre the nerve impulse is of constant size but the stronger the stimulus, the greater the frequency of the impulses discharged along the nerve....

Against this background is set the crucial clinical experimentation of Head and Rivers. Sir Henry Head, who was Rivers' friend and co-worker, is a familiar giant of British neurology [1] about whom much has been written [2], but neurologists should also remember Rivers for his ground-breaking work with Head on the evolving sensory signs after section of Head's own peripheral nerve. William Rivers [MD Lond., FRCP Lond., FRS] was a most unusual man (fig. 1). He was a polymath with careers in neuroscience, ethnology, and psychology. But above all - despite or perhaps because of personal nervous constraints - he was a man of unusual humanity.

This classical and courageous ${ }^{1}$ experiment was instigated by Head, who had become increasingly frustrated by the unreliability of the average patient as a sensory witness [3]. Head had noticed in his patients loss of some sensations and retention of others in many cases of peripheral nerve injury. Observing variable areas of sensory loss after median and ulnar nerve division, he asked: 'What is meant by diminished sensibility?' and 'To what is it due?'

At this time there were of course neither antibiotics nor blood transfusion for treatment of possible complications.
J.M.S. Pearce

304 Beverley Road

Anlaby, East Yorks HU10 7BG (UK) 


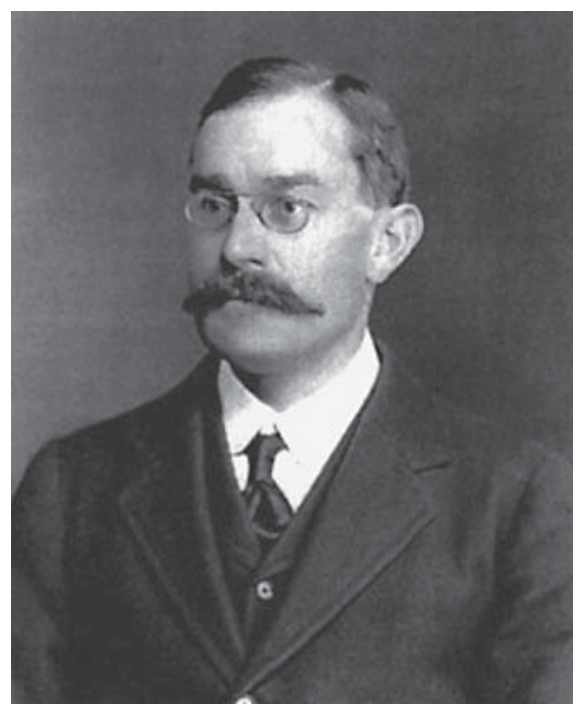

Fig. 1. William Rivers (from http://www.greatwar.nl/).

It was in Cambridge where Head with Rivers began the experiment that continued until December 1907. In 1903, Head persuaded his colleague, the surgeon James Sherren, to divide the superficial ramus of his own left radial nerve. After the operation he spent weekends at St. John's College, Cambridge, where he and Rivers repeatedly mapped the sensory loss caused by the nerve section and the subsequent changes during regeneration $[4,5]$. At first they observed that the vascular signs began to return to normal in 107 days and were quite normal in 190 days. As a result, Head came to believe that there were three distinct forms of peripheral sensation: deep, protopathic, and epicritic [6]. Fibres that ran mainly with muscular nerves served deep sensibility. They were proprioceptive, mediating pressure stimuli as well as joint and muscle movements. The results were first published in Brain in 1908 [7] and were widely acclaimed.

Head later remarked: 'For five happy years we worked together on weekends and holidays in the quiet atmosphere of (Rivers') rooms in St John's College.'

Rivers [8] summarised their findings:

Observations on the sensory changes which accompany the regeneration of a divided and reunited nerve have led Head and his colleagues to distinguish two different kinds of mechanism on the afferent side of the nervous system. Prolonged observations after the division of nerves in Head's own arm brought out clearly the existence of two definite stages in the return of sensibility. In one of these, the protopathic stage, the sensations are vague and crude in character, with absence of any exactness in discrim- ination or localisation and with a pronounced feeling-tone, usually on the unpleasant side, tending to lead immediately, as if reflexly, to such movements as would withdraw the stimulated part from contact with any object to which the sensory changes are due. At this stage of the healing of the reunited nerve there are present none of those characters of sensation by which we recognise the nature of an object in contact with the body. The sensations are such as would enable one to know that something is there and that it is pleasant or unpleasant. It is also possible to distinguish between mere contact or pressure and stimulation by heat or cold, but within each of these modes of sensation there is no power of distinguishing differences in intensity nor of telling with any exactness the spot where the processes underlying the sensory changes are in action.

The second stage of the process of regeneration is characterised by the return of those features of normal cutaneous sensibility, such as exact discrimination and localisation, by means of which it becomes possible to perceive the nature of an object in contact with the skin and adjust behaviour according to this perception. The modes of reaction which make this exactness of discrimination and power of external projection possible are grouped together under the heading of epicritic sensibility. ...

In interpreting these observations two chief possibilities are open. Epicritic sensibility may be only a greater perfection of protopathic sensibility, experience gradually enabling an exactness of discrimination.... The way in which epicritic sensibility returns and the fact that it is possible to annul it by treatment affecting only the peripheral factors, without influence on such central processes as would be set up by experience, go far to show that the two modes of sensibility represent two stages in phylogenetic development.

Protopathic sensibility was 'capable of responding to painful cutaneous pressure and thermal stimuli and extremes of heat and cold'. Protopathic pain was generated in the posterior nerve roots and showed the highest threshold for a pain response with poor localisation, failure to adapt, and an intense response to stimulation. Epicritic sensibility was the ability to make fine discrimination of touch and temperature sensations, as well as the ability to localise and discriminate sensation. Epicritic sensation was more precisely tuned than protopathic sensation, and epicritic pain fibres were found throughout the peripheral nervous system with slower regeneration times.

This experiment, important as it was, led to further investigations of sensation in which Head began to reveal an organisation of sensory afferents [6, 9]. Examining many patients with herpes zoster, Head and Campbell had in 1900 mapped the skin eruptions [10] to relate specific dermatomes to an affected nerve root [11]. From this data, they created the first accurate map of the human dermatomes [10]. Head also conducted extensive investigations of the 'sensory disturbances from cerebral lesions' with Gordon Holmes. 
Rivers' and Head's ideas evolved. The names protopathic and epicritic sensations have now fallen into disuse. Erlanger and Gasser's Nobel Prize (1944) work showed that nerve fibres, according to their conduction velocities, fell into three main groups. The thickest mammalian A fibres conduct impulses from 10 to $100 \mathrm{~m} / \mathrm{s}$; the thinnest, the $\mathrm{C}$ fibres, have conduction velocities from 0.6 to $2 \mathrm{~m} / \mathrm{s}$. The B fibres have conduction velocities from 3 to $15 \mathrm{~m} / \mathrm{s}$. Very thin, slowly conducting fibres largely mediate pain; muscle sense, movement and touch are subserved by rapidly conducting fibres. These equate to A fibres mediating epicritic pain perception and $\mathrm{C}$ fibres mediating protopathic pain. Otfried Foerster disclosed the central role of inhibition in providing analgesia, later developed by Melzack and Wall's 'gate control theory' of 1965. In the 1970s the midline mesencephalic and medullary nuclei were shown to contain opium receptors and to release opioids, and the concept of central pain developed.

\section{William Rivers}

Son of a churchman, Rivers was born in Luton, near Chatham in Kent, and attended Tonbridge School. He read Medicine at St. Bartholomew's Hospital, qualifying in 1886. He then tried to join the Royal Army Medical Corps but was found unfit. In his biography a close friend, Grafton Elliot Smith [12], wrote: 'Rivers always had to fight against ill health: heart and blood vessels.' $\mathrm{He}$ became house surgeon at Chichester Infirmary (1887-1889) and house physician at St. Bartholomew's Hospital (1889-1890). In 1891 he joined the Neurological Society and became house physician at the National Hospital for the Paralysed and Epileptic where he met Hughlings Jackson, Michael Foster, Henry Head, and Charles S. Sherrington. He secured the MD London and FRCP London. With Victor Horsley he investigated the nature of electrical currents in the mammalian brain, at University College. He left the National Hospital in 1892 [13] and travelled to Jena where he worked with Ewald Hering. During his visit his diary discloses a turning point in his ambitions: 'I have during the last three weeks come to the conclusion that I should go in for insanity when I return to England and work as much as possible at psychology.'

He was appointed clinical assistant at Bethlem Royal Hospital, and gave lectures on mental illnesses at Guy's Hospital. He also studied and lectured on experimental psychology. In 1893 Rivers taught physiology at Cam- bridge and spent that summer working in Heidelberg with Emil Kräpelin, investigating the physiology of fatigue [14]. On 7th December 1897, he was appointed lecturer in Physiological and Experimental Psychology in Cambridge.

Instead of the army, his love of travel led him to work as a ship's surgeon, travelling to Japan and America. In his travels [15], he pioneered the experimental study of mental functions among preliterate islanders of the Torres Strait testing the 'fairly unanimous' attribution 'to savage and semi-civilized races [of] a higher degree of acuteness of sense than is found among Europeans'. His work was recognised by election as a Fellow of the Royal Anthropological Institute in 1890. He introduced genealogical methods into sociology in his study, The Todas (1906). Visiting Melanesia in 1908 his studies yielded The History of Melanesian Society (1914). Later books resulted from his attempts to link his observations on ethnology with psychoanalytic theory. On one expedition he encountered George Bernard Shaw spending 'many hours every day talking - the greatest treat of my life'.

He himself suffered a febrile illness and subsequently was seriously limited by intractable tiredness, which would now be regarded as chronic fatigue syndrome. Seligman [16] wrote in 1922: 'For many years he seldom worked for more than four hours a day.' Rivers was prone to stammer - described in Chapter II of his Instinct and the Unconscious. He was appointed lecturer in psychology at St. John's College in Cambridge in 1897 and became a Fellow in 1902. In 1907 he was appointed to the newly established lectureship of Physiology and Experimental Psychology and made director of the Cambridge new psychology laboratory, the first of its kind in Great Britain. He became Joint Editor of the British Journal of Psychology. In May 1908 he was elected to the Royal Society, and was awarded its Royal Medal in 1915.

World War I led him to new approaches to shell shock estimated as affecting $7-10 \%$ of the officers and $3-4 \%$ of other ranks. Rivers maintained that war neuroses did not result from war experiences themselves, but were 'due to the attempt to banish distressing memories from the mind'. He encouraged his patients to remember, instead of trying to forget what they had been through: a precursor of abreaction therapy.

On 4th December 1917, he addressed the Section of Psychiatry of the Royal Society of Medicine on the 'Repression of War Experience'. In February 1918, this paper was published in The Lancet [17]: 
Because I advocate the facing of painful memories and deprecate the ostrich-like policy of attempting to banish them from the mind, it must not be thought that I recommend the concentration of the thoughts on just such memories. On the contrary, in my opinion it is just as harmful to dwell persistently upon painful memories or anticipations and brood upon feelings of regret and shame as to banish them wholly from the mind.

When commissioned in 1916, as Captain in the Royal Army Medical Corps, he applied this principle, to treat shell-shocked officers at Craiglockhart Hospital, near Edinburgh. Rivers was much loved and admired. Among his patients were Siegfried Sassoon (1886-1967) and Wilfred Owen (1893-1918). Sassoon appears in Rivers' work on shell shock while Rivers appears in several poems written by Sassoon after World War I. Sassoon's fictionalised autobiography, The Complete Memoirs of George Sherston (1980), extols him almost as a demigod who saved his life and soul. In his preface to Medicine, Magic and Religion, 1924, Sassoon wrote: 'I would very much like to meet Rivers in the next life. It is difficult to believe that such a man as he could be extinguished.'

The novelist Pat Barker fictionalised his life and meetings with Sassoon in three highly praised books: Regen- eration (1991), The Eye in the Door (1993) and The Ghost Road (1995), the latter receiving the 1995 Man Booker Prize.

After the War, Rivers returned to Cambridge where he concentrated on his work on psychology, sociology and ethnology. He died on 4th June, 1922 from a strangulated hernia. The distinguished scholar Sir Frederick Bartlett (1886-1969) wrote:

Never have I known so deep a gloom settle upon the College [St. John's, Cambridge] as fell upon it at that time. There was hardly a man - young or old - who did not seem to be intimately and personally affected. Rivers knew nearly everybody.

At various times this remarkable polymath made valued contributions as experimental psychologist, author, anthropologist studying an exotic south Indian hill tribe, experimental neurologist who for 5 years observed sensory regeneration in Henry Head's arm, psychotherapist earning lavish praise from his shell-shocked patients. Remarkable too, because poor health made him allegedly unable to work for more than $4 \mathrm{~h}$ a day.

His portrait (NPG x104465) by Walter Stoneman in 1917 is in the National Portrait Gallery, London.

\section{References}

1 Pearce JMS: Henry Head. J Neurol Neurosurg Psychiatry 2000;69:578

$\checkmark 2$ Brain R: Henry Head: the man and his ideas [including Head's bibliography]. Brain 1961; 84:561-571.

3 Critchley M: The Black Hole and Other Essays. London, Pitman, 1964, pp 98-107.

4 Head H, Rivers WHR, Sherren J: The afferent nervous system from a new aspect. Brain 1905;28:99-115.

5 Head H, Sherren J: The consequences of injury to the peripheral nerves in man. Brain 1905;28:116-338

6 Head H: Studies in Clinical Neurology. London, Hodder \& Stoughton, 1920, pp 334728.
Rivers WHR, Head H: A human experiment in nerve division. Brain 1908;31:323-450.

8 Rivers WHR: Instinct and the Unconscious: A Contribution to a Biological Theory of the Psycho-Neuroses. Cambridge, Cambridge University Press, 1920, chap 4.

9 Henson RA: Henry Head: his influence on the development of ideas on sensation. $\mathrm{Br}$ Med Bull 1977;33:91-96.

10 Head H, Campbell AW: The pathology of herpes zoster and its bearing on sensory localization. Brain 1900;23:353-529.

11 Head H: The grouping of afferent impulses within the spinal cord. Brain 1906;29:537541.
12 Elliot Smith G: Preface; in Rivers WH: Conflict and Dream. London, Kegan Paul, Trench, Trubner, 1923.

13 Head H: Obituary notice of William Halse Rivers Rivers. Proc R Soc 1923;1-5.

14 Adams CE: William Halse Rivers (18641922). http://www.jameslindlibrary.org/trial_records/20th_Century/1900_1920/rivers/rivers_biography.html.

15 Slobodin R: W.H.R. Rivers: Pioneer Anthropologist, Psychiatrist of The Ghost Road. Reprint, Stroud, Sutton, 1997 (New York, Columbia University Press, 1978).

16 Seligman CG: Obituary: Dr. WHR Rivers. Geogr J 1922;60:162-163.

17 Rivers WH: The repression of war experience. The Lancet 1918;194:173-174. 